\title{
Human Pancreatic Polypeptide Secretion in Conditions of Exogenous and Endogenous Hyperglycaemia
}

\author{
J. Marco, J. A. Hedo, J. Castillo-Olivares ${ }^{1}$, and María L. Villanueva \\ Clínica Puerta de Hierro, Universidad Autónoma de Madrid, and ${ }^{1}$ Instituto de Diabetología de la Cruz Roja, Madrid, Spain
}

Summary. The effects of exogenous and endogenous hyperglycaemia on human pancreatic polypeptide secretion have been studied. In normal subjects elevation of plasma glucose concentration by glucose infusion both depressed the basal levels of circulating human pancreatic polypeptide (by $40-50 \%$ ) and consistently reduced the human pancreatic polypeptide response to the ingestion of a protein-rich meal (areas above pre-meal value: $19.5 \pm 4.1$ (mean \pm SEM) vs. $9.6 \pm 2.1, \mathrm{p}<0.01$ ) as well as to caerulein infusion (areas above pre-caerulein value: $8.8 \pm 2.2$ vs. $4.6 \pm 1.4, \mathrm{p}<0.01$ ). In diabetic subjects treated with sulphonylureas or diet (fasting plasma glucose: $166 \pm 11 \mathrm{mg} / \mathrm{dl}, \mathrm{n}=24$ ), human pancreatic polypeptide secretion evoked by food was similar to that of 24 healthy individuals (areas above basal value: $46.6 \pm 9.9$ and $33.6 \pm 3.6$, respectively). In insulin dependent diabetics (fasting plasma glucose: $231 \pm$ $19 \mathrm{mg} / \mathrm{dl}, \mathrm{n}=21$ ) the human pancreatic polypeptide response to the meal (area above basal value: 78:2 \pm 13.7) was significantly greater than that of the controls as well as that of the noninsulin-dependent group $(p<0.05)$. Since the administration of pancreatic polypeptide to man has been shown to decrease pancreatic exocrine output, postprandial human pancreatic polypeptide hypersecretion may contribute to the decreased exocrine function of the pancreas often found in insulin-dependent diabetics.

Key words: Human pancreatic polypeptide, glucose, protein meal, caerulein, normal subjects, noninsulindependent diabetics, insulin-dependent diabetics.

In the course of insulin purification from chicken pancreas, Kimmel and associates found a new polypeptide consisting of 36 amino acid residues [1, 2].
They have termed this molecule avian pancreatic polypeptide (aPP). Subsequently, an immunologically related substance was demonstrated in pancreatic extracts of several other species [3]. Chance et al., independently, isolated and characterized a homologous peptide from extracts of human, porcine, ovine and bovine pancrea [4]. Larsson et al. [5], have identified the storage site of pancreatic polypeptide in islet cells distinct from A, B and D cells.

In the chick, administration of aPP provokes depletion of liver glycogen and a reduction of plasma glycerol [6], but pancreatic polypeptide has not been shown to display metabolic effects in mammals $[7,8]$. Floyd et al. [9] have described an elevation of basal pancreatic polypeptide plasma levels in patients with diabetes mellitus. Furthermore, in normal subjects circulating human pancreatic polypeptide (hPP) concentrations are inversely affected by experimental fluctuations in glycaemia $[9,10]$ thus suggesting an effect on hPP secretion by glucose.

The present work was designed to evaluate hPP secretion in conditions of exogenous and endogenous hyperglycaemia.

\section{Materials and Methods}

\section{Subjects and Procedures}

The effect of exogenous hyperglycaemia on hPP secretion was examined in healthy, non-obese volunteers ( 8 males and 4 females; age range 19 to 25 years, mean 21.3). Glucose was administered IV as a bolus $(0.33 \mathrm{~g} / \mathrm{kg}$ body weight $)$ followed by a constant infusion $(0.6$ or $0.9 \mathrm{~g} / \mathrm{min}$ as $10 \mathrm{~g} / 100 \mathrm{ml}$ or $15 \mathrm{~g} / 100 \mathrm{ml}$ solutions, respectively) for 60 or $90 \mathrm{~min}$. In control experiments, an identical volume of $0.154 \mathrm{~mol} / 1$ saline was given.

To provoke hPP secretion two different stimuli were employed: 1) A protein-rich meal ( $70 \mathrm{~g}$ smoked pork loin, one boiled egg, and $15 \mathrm{~g}$ white bread) consumed in $10 \mathrm{~min}$; 2) Caerulein (Montedison Farmaceútica, $50 \mathrm{ng} / \mathrm{kg}$ body weight) dissolved in $10 \mathrm{ml}$ of $0.154 \mathrm{~mol} / \mathrm{l}$ saline and infused IV over a 10 -minute 


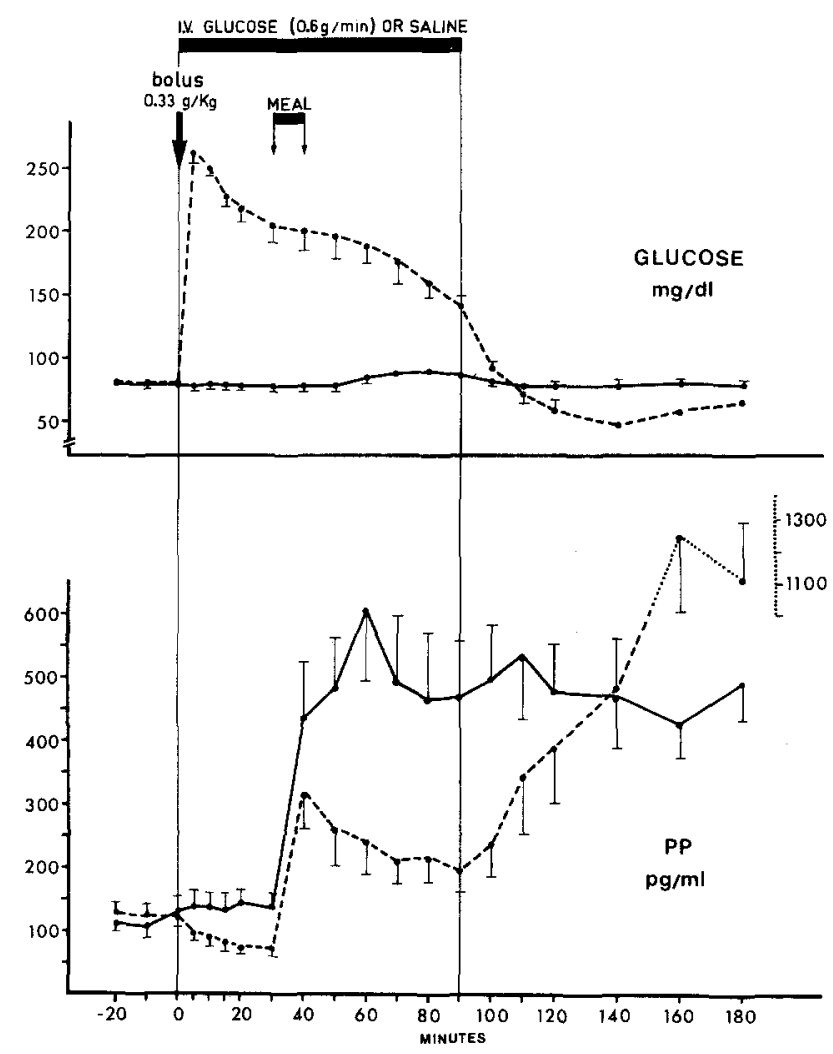

Fig. 1. Effect of IV glucose on the hPP response to a protein-rich meal in 12 normal subjects (mean \pm SEM). The solid and broken lines correspond to the control and glucose experiments, respectively. The hPP values from 5 to $30 \mathrm{~min}$ as well as the integrated hPP response (area above pre-meal value) are significantly lower in the glucose than in the control experiments

period. These stimuli were applied 20 or 30 min after initiating glucose administration. Each subject served as his own control and the order of the glucose and saline tests was randomised.

In a second series of experiments the hPP response to a protein-rich meal was investigated in normal and diabetic subjects. In these tests the standard breakfast comprised $70 \mathrm{~g}$ smoked pork loin and $15 \mathrm{~g}$ white bread. The control group consisted of 24 healthy individuals (13 males and 11 females, age range 24 to 59 years, mean 42 ), whose body weight ranged $-10 \%$ to $11 \%$ (mean $2 \%$ ) of the ideal according to the Metropolitan Life Insurance Company tables. None were taking any medication. Two groups of diabetics were studied. The first group consisted of 21 insulin-dependent patients (13 males and 8 females, age range 16 to 60 years, mean 36 ) in whom the disease had been diagnosed from 0.2 to 11 years previously (mean 5 ). Their body weight fell between $-10 \%$ and $7 \%$ of the ideal (mean $-1 \%$ ). Daily insulin requirements ranged from 10 to $64 \mathrm{U}$ (mean 32).

All patients selected for this study lacked circulating PP antibodies, as determined by previous screening. The presence of PP antibodies was investigated by examining the binding of radiolabelled PP to plasma samples in the absence of rabbit antiPP serum. In our assay, the nonspecific binding of the solutions containing standard hPP has ranged from 4 to $9 \%$. Those diabetics whose plasma bound a greater percentage of radiolabelled $P P$ than that corresponding to the hPP standard samples, were not included in these experiments.

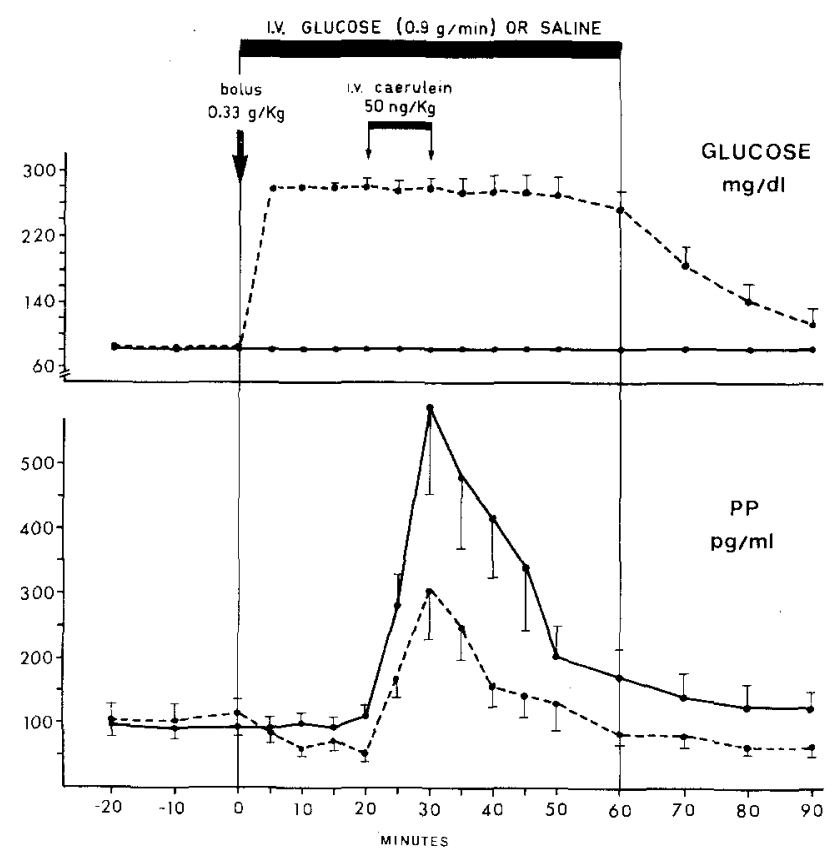

Fig. 2. Effect of IV glucose on the hPP response to IV caerulein in 11 normal subjects (mean $\pm \mathrm{SEM}$ ). The solid and broken lines correspond to the control and glucose experiments, respectively. The hPP values from 10 to $20 \mathrm{~min}$ as well as the integrated hPP response (area above pre-caerulein value) are significantly lower in the glucose than in the control experiments

The second group of diabetics consisted of 24 non-insulindependent subjects (12 males and 12 females, age range 37 to 66 years, mean $50, p=0.013$ vs. controls and $p=0.002$ vs. insulin-dependent diabetics) in whom diabetes was diagnosed from 0.1 to 16 years previously (mean 5 ). Their body weight fell between $-9 \%$ and $10 \%$ of the ideal (mean -1 ). Eighteen patients were being treated with diet and sulphonylurea therapy and the remaining six were being controlled by diet alone. The diabetics of both groups suffered from no other apparent illness at the time of the study, and no antecedent pancreatitis had been recorded. None were taking drugs other than insulin or sulphonylurea. The proportion of males to females between the groups of control subjects, insulin-dependent patients and noninsulindependent diabetics was not significantly different, as analysed by the chi-square test. The mean ages of males and females were similar within each group. Informed consent was obtained.

Volunteers reported to the laboratory at $0900 \mathrm{~h}$ after an overnight fast. Blood specimens $(7 \mathrm{ml})$ were drawn from an antecubital vein, placed in chilled tubes containing EDTA (final dilution $2.9 \mathrm{mM}$ ) and promptly centrifuged at $4^{\circ} \mathrm{C}$. The plasma was stored at $-20^{\circ} \mathrm{C}$ until the time of assay not more than four weeks later.

\section{Analytical Methods}

All samples were tested in duplicate. Plasma glucose was determined by means of a commercial glucose-oxidase preparation (Biochemica Test Combination, Boehringer Mannheim). Plasma hPP was assayed radioimmunologically [10] employing rabbit antihPP serum (lot \# 615-1054B-248-19), hPP (lot \#615-1054B-200) as standard, and bovine pancreatic polypeptide (lot \#615-D63188-9) for iodination. All of these substances were kindly donated 
by Dr. Ronald E. Chance (Lilly Research Laboratories, Eli Lilly Co., Indianapolis, U.S. A.). In our assay, the minimal detectable concentration with $95 \%$ of confidence is $17 \mathrm{pg} / \mathrm{ml}$. The slope of the logit dose response curve is $-2.1 \pm 0.16(\mathrm{SD})$ and the intercept when $\mathrm{B} / \mathrm{T}$ is $1 / 2$ of $(\mathrm{B} / \mathrm{T})_{0}$ corresponds to $21 \pm 2.6$ (SD) $\mathrm{pg}$ in the incubation tube. The within-assay and between-assay coefficients of variation are $8.8 \%$ and $16.5 \%$, respectively.

Data are presented as the mean $\pm \mathrm{SEM}$. Statistical significance of differences between plasma glucose values was calculated by Student's t test. The Wilcoxon rank sum test for paired observations and the Mann Whitney $\mathbf{U}$ test for unpaired observations were employed to calculate statistical significance of differences between plasma hPP levels.

\section{Results}

Effect of Intravenous Glucose on the hPP Response to a Protein-rich Meal in Normal Subjects (Fig. 1)

In the control experiments, mean fasting hPP level (average of three determinations) was $118 \pm 19 \mathrm{pg} /$ $\mathrm{ml}$. The infusion of saline for $30 \mathrm{~min}$ had no effect. Immediately after the ingestion of the meal, an elevation of circulating hPP was found $(435 \pm 90 \mathrm{pg} / \mathrm{ml}$ at 40 min, $p<0.01$ ) which persisted for the remainder of the experimental period, with values ranging from $608 \pm 126 \mathrm{pg} / \mathrm{ml}(\mathrm{p}<0.01$, at $60 \mathrm{~min})$ to $427 \pm$ $50 \mathrm{pg} / \mathrm{ml}(\mathrm{p}<0.01$, at $160 \mathrm{~min})$.

When glucose was infused, basal plasma hPP $(127 \pm 15 \mathrm{pg} / \mathrm{ml})$ declined progressively $(100 \pm$ $15 \mathrm{pg} / \mathrm{ml}$ at $5 \mathrm{~min}, \mathrm{p}<0.01 ; 73 \pm 9 \mathrm{pg} / \mathrm{ml}$ at $30 \mathrm{~min}$, $\mathrm{p}<0.01)$. The subsequent hPP rise observed after consumption of the meal (maximal value: $323 \pm$ $64 \mathrm{pg} / \mathrm{ml}$, at $40 \mathrm{~min}$ ) was diminished with respect to the control series. The differences between the mean increments above the pre-meal value (range: $157-299 \mathrm{pg} / \mathrm{ml}$ ) were statistically significant from 50 to $90 \mathrm{~min}$. Furthermore, the hPP response, as expressed by the area above the pre-meal value (between 30 and $90 \mathrm{~min}$ ), was smaller in the glucose $(9.6$ $\pm 2.1)$ than in the saline experiments $(19.5 \pm 4.1, \mathrm{p}$ $<0.01$ ). Upon cessation of the glucose infusion, plasma hPP concentrations rose to levels markedly higher than those provoked by the meal. This rise coincided with a fall in plasma glucose to subbaseline values.

\section{Effect of Intravenous Glucose on the hPP Response to Caerulein in Normal Subjects (Fig. 2)}

In the saline experiments, caerulein infusion $(50 \mathrm{ng} /$ $\mathrm{kg}$ body weight) elicited a clear rise in plasma hPP levels (basal value: $94 \pm 15 \mathrm{pg} / \mathrm{ml}$; peak: $590 \pm 135$, $\mathrm{p}<0.01$ ). Intravenous administration of glucose depressed fasting hPP concentrations (basal value: 108 $\pm 22 \mathrm{pg} / \mathrm{ml} ; 20$-min value: $53 \pm 12 \mathrm{pg} / \mathrm{ml}, \mathrm{p}<0.02$ )
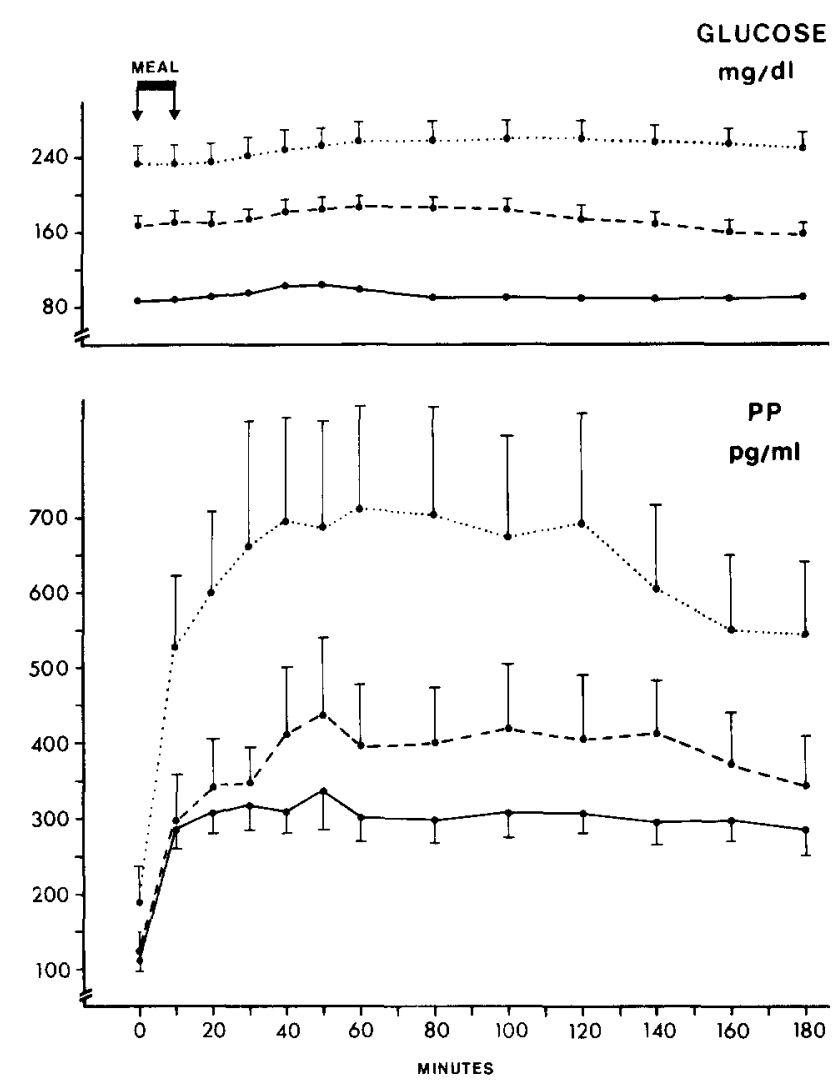

Fig. 3. hPP response to a protein-rich meal in 24 control subjects (solid line), 24 non-insulin-dependent diabetics (broken line) and 21 insulin-dependent diabetics (dotted line) (mean \pm SEM). The integrated $\mathrm{hPP}$ response (area above basal value) of the insulindependent group is significantly greater than both that of the control and non-insulin-dependent groups

and inhibited the hPP elevation evoked by caerulein (peak: $308 \pm 80 \mathrm{pg} / \mathrm{ml}, \mathrm{p}<0.01$ ). The differences between the mean increments above the pre-caerulein value were statistically significant from 30 to $45 \mathrm{~min}$ (range: $145-225 \mathrm{pg} / \mathrm{ml}$ ). Moreover, during glucose administration, the hPP response, as calculated by the incremental area above the pre-caerulein value (between 20 and $60 \mathrm{~min}$ ), was smaller than that of the control series $(4.6 \pm 1.4$ vs. $8.8 \pm 2.3$, $\mathrm{p}<0.01)$.

\section{hPP Response to a Protein-rich Meal in Normal and Diabetic Subjects (Fig. 3)}

In normal subjects, the fasting plasma hPP level was $111 \pm 13 \mathrm{pg} / \mathrm{ml}$. Ingestion of the meal was followed by an elevation of circulating hPP which persisted throughout the experimental period (area above basal value: $33.6 \pm 3.6$ ). In the noninsulin-dependent diabetics (basal plasma glucose $166 \pm 11 \mathrm{mg} / \mathrm{dl}$ ) fasting hPP concentration $(121 \pm 24 \mathrm{pg} / \mathrm{ml})$ as well as the hPP response to the meal (area above basal 
value: $46.6 \pm 9.9$ ) were not statistically different from those of the controls. In the insulin-dependent patients (basal plasma glucose $231 \pm 19 \mathrm{mg} / \mathrm{dl}, \mathrm{p}$ $<0.01$ vs. noninsulin-dependent diabetics), the fasting hPP level was $193 \pm 47 \mathrm{pg} / \mathrm{ml}(\mathrm{p}=0.4$ vs. controls) and the elevation of plasma hPP evoked by the meal (area above basal value: $78.2 \pm 13.7$ ) was greater than that of the control group $(p<0.01)$ as well as that of the noninsulin-dependent diabetics $(\mathrm{p}<0.05)$.

\section{Discussion}

Our data confirm the depressor effect of hyperglycaemia, as induced by IV glucose administration, on basal plasma levels of hPP in normal subjects. They also show that under this circumstance, the hPP response to food ingestion as well as to the infusion of caerulein appears markedly reduced. It is of note that Adrian et al. [11], using the isolated canine pancreas, found no influence of glucose on pancreatic polypeptide release, thus suggesting that glucose does not directly affect the secretory activity of the PP-cell. Since cholinergic blockage inhibits PP output $[12,13,14]$, it is conceivable that acute hyperglycaemia reduces hPP secretion through a vagally mediated mechanism. A similar conjecture has been suggested by MacGregor et al. [15] to explain the suppressant effect of rising blood sugar levels on gastrin and gastric acid secretion.

In contrast, the insulin-dependent diabetics, who were markedly hyperglycaemic, responded to the protein-rich meal with a marked hPP hypersecretion. On the other hand, in the non-insulin-dependent diabetics the hPP response to the meal was not different from that of the normal subjects and significantly smaller than that of the insulin-treated patients. These data are in agreement with the report of Floyd et al. [9], who found higher fasting hPP values in diabetics receiving insulin than in both control subjects and in those patients treated with diet or sulphonylureas. In our series of insulin-dependent diabetics the mean basal hPP level was higher than that of the healthy individuals and also that of the noninsulin-dependent patients. However, these differences were not statistically significant.

At present, it seems difficult to interpret the hypersecretion of hPP in insulin-dependent diabetics. It is known that basal hPP levels increase with age [9, $10,16]$. However, in our study the mean age of the insulin-treated patients was similar to that of the controls and significantly less than that of the noninsulindependent group. The non-insulin-dependent diabetics were significantly older than the normal individuals. This may have accounted for their slightly greater, though not statistically significant, hPP response as compared to the controls. It has been shown that in healthy obese subjects there is a reduction of basal hPP concentrations as well as a diminished $h P P$ response to a meal $[17,18]$. In our series, none of the subjects were obese and the mean body weight of the control and diabetic individuals was similar. Track et al. [16] have reported that male subjects have higher fasting hPP concentrations than females. The proportion of males to females in the three groups studies was similar. Floyd et al. [9] have discussed the tendency of plasma hPP levels to rise with the clinical severity of diabetes, as determined by the degree of fasting hyperglycaemia. In our patients, there was no correlation between basal glycaemia and the integrated response to the meal. On the other hand, Gepts and De Mey [19] have presented histological evidence of an increased population of PP-cells in the pancreas of juvenile diabetics. According to them, the PP-cell hyperplasia represents atypical regeneration of the damaged islet and would be more prominent in longstanding cases of the disease. There was no correlation, however, in our series, between the duration of diabetes and the magnitude of the hPP secretion evoked by the meal.

It is uncertain whether elevated hPP plasma levels in insulin-dependent diabetics have any pathological significance. However, the administration of bovine pancreatic polypeptide to man [20] and dogs [7] has been shown to reduce pancreatic exocrine output. Thus, postprandial hPP hypersecretion could contribute to the decreased exocrine function of the pancreas, often found in these patients [21].

Acknowledgements. This work was supported by a research grant from the Instituto Nacional de la Salud (Spain). We wish to thank Dr. R. E. Chance (Lilly Research Laboratories, Indianapolis, U.S. A.) for his generous supply of the reagents for hPP radioimmunoassay, and Dr. J. L. Iriarte (Montedison Farmaceútica, Barcelona, Spain) for his gift of caerulein. The technical assistance of Ms. Pilar García, Ms. Begoña Samper and Ms. Ana Ramírez is gratefully appreciated.

\section{References}

1. Kimmel JR, Pollock HG, Hazelwood RL (1968) Isolation and characterization of chicken insulin. Endocrinology 83: $1323-1330$

2. Kimmel JR, Hayden LJ, Pollock HG (1975) Isolation and characterization of a new pancreatic polypeptide hormone. J Biol Chem 250: 9369-9376

3. Langslow DR, Kimmel JR, Pollock HG (1973) Studies on the distribution of a new avian pancreatic polypeptide and insulin among birds, reptiles, amphibians and mammals. Endocrinology 93: 558-565 
4. Chance RE, Lin T-M, Johnson MG, Moon NE, Evans DC, Jones WE, Koffenberger Jr JE (1975) Studies on a newly recognized pancreatic hormone with gastrointestinal activities. Programme of the 57th Annual Meeting of the Endocrine Society, New York (Abstract 265)

5. Larsson L-I, Sundler F, Hakanson R (1975) Immunohistochemical localization of human pancreatic polypeptide (hPP) to a population of islet cells. Cell Tissue Res 156: 167-171

6. Hazelwood RL, Turner SD, Kimmel JR, Pollock HG (1973) Spectrum effects of a new polypeptide (third hormone?) isolated from the chicken pancreas. Gen Comp Endocrinol 21: $485-497$

7. Lin T-M, Evans DC, Chance RE, Spray GF (1977) Bovine pancreatic peptide: action on gastric and pancreatic secretion in dogs. Am J Physiol 232: E 311-E 315

8. Adrian TE, Greenberg GR, Besterman HS, McCloy RF, Chadwick VS, Barnes AJ, Mallinson CN, Baron JH, Alberti KGMM, Bloom SR (1978) PP infusion in mansummary of initial investigations. In: Bloom SR (ed) Gut hormones. Churchill Livingstone, Edinburgh, p 265-267

9. Floyd JC Jr, Fajans SS, Pek S, Chance RE (1977) A newly recognized pancreatic polypeptide: plasma levels in health and disease. Recent Prog Horm Res 33: 519-570

10. Marco J, Hedo JA, Villanueva ML (1978) Control of pancreatic polypeptide secretion by glucose in man. J Clin Endocrinol Metab 46: 140-145

11. Adrian TE, Bloom SR, Hermansen K, Iversen J (1978) Pancreatic polypeptide, glucagon and insulin secretion from the isolated perfused canine pancreas. Diabetologia 14: 413-417

12. Taylor IL, Feldman M, Richardson CT, WaIsh JH (1978) Gastric and cephalic stimulation of human pancreatic polypeptide release. Gastroenterology 75: 432-437

13. Schwartz TW, Holst JJ, Fahrenkrug J, Lindkaer Jensen S, Nielsen OV, Rehfeld JF, Schaffalitzky de Muckadell OB, Stadil F (1978) Vagal, cholinergic regulation of pancreatic polypeptide secretion. J Clin Invest 61: 781-789
14. Hedo JA, Villanueva ML, Marco J (1978) Stimulation of pancreatic polypeptide and glucagon secretion by 2 -deoxy-D-glucose in man: evidence for cholinergic mediation. $\mathrm{J}$ Clin Endocrinol Metab 47: 366-371

15. MacGregor IL, Deveney C, Way LM, Meyer JH (1976) The effect of acute hyperglycaemia on meal-stimulated gastric, biliary, and pancreatic secretion and serum gastrin. Gastroenterology 70: 197-202

16. Track NS, Watters LM, Gauldie J (1979) Motilin, human pancreatic polypeptide (HPP) and gastrin plasma concentrations in fasting subjects. Clin Biochem 12: 109-117

17. Lassmann V, Simon MC, Altomare E, Vague PH (1979) Plasma pancreatic polypeptide (PP) levels in obese subjects. Programme of the 10th Congress of the International Diabetes Federation, Vienna, Austria (Abstract 349)

18. Marco J, Zulueta MA, Correas I, Villanueva ML (1980) Reduced pancreatic polypeptide secretion in obese subjects. J Clin Endocrinol Metab 50: 744-747

19. Gepts W, De Mey J (1978) Islet-cell survival determined by morphology. Diabetes 27 (Suppl 1): 251-261

20. Greenberg GR, Adrian TE, Baron JH, McCloy RF, Chadwick VS, Bloom SR (1978) Inhibition of pancreas and gallbladder by pancreatic polypeptide. Lancet II: $1280-1282$

21. Jenson WK (1971) The digestive system and diabetes: In: Marble A, White P, Bradley RF, Krall LP (eds) Joslin's diabetes mellitus. Lea \& Febiger, Philadelphia, p 708-721

Received: November 5, 1979,

and in revised form: June 10,1980

Dr. José Marco

Clínica Puerta de Hierro

Universidad Autónoma de Madrid

San Martín de Porres 4

Madrid 35

Spain 